\title{
JOURNAL.RU
}

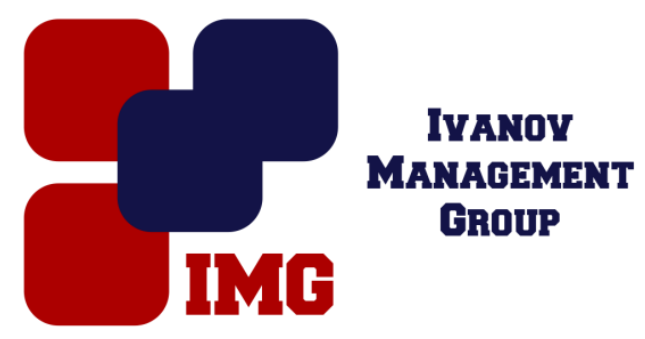

Левчук.А.Д.

doi: $10.18411 / \mathrm{lj}-31-05-2017-44$

idsp 000001:1j-31-05-2017-44

\section{Русская цивилизация и Золотая Орда}

\section{Аннотация}

В статье рассматриваются взаимоотношения Золотой Орды и Руси в период татаро-монгольского ига. На основе данной темы автором раскрывается проблема влияния Золотой Орды на развитие Руси как государства. С привлечением научной литературы по выбранной теме были критически проанализированы четыре аспекта взаимодействия двух государств. Были выявлены расхождения во мнениях знаменитых историков относительно одних и тех же событий и явлений. Автор делает вывод об отсутствии негативного влияния Орды на Русь.

Ключевые слова: русская цивилизация, Золотая Орда, право, государство

В эпоху переосмысления истории Российского государства неверным было бы обойти стороной вопрос татаро-монгольского ига и его влияния на развитие российской государственности и общества. Столкновение этих миров осмысляется в нашей стране в форме «столкновения цивилизаций». «Концепциялокальных цивилизаций вновь демонстрирует эвристический потенциал»[Ошибка! Источник ссылки не найден., с. 96]. Историки, в русле этого направления, пытаются ответить на следующие вопросы: было ли вообще иго как таковое; какой след в истории России оставил культурный обмен между Золотой Ордой и Русью.

Многие известные историки занимались изучением данных вопросов. В этой статье мы сравним и противопоставим мнения нескольких специалистов 
исторической науки: Э.С. Кульпина, В.А. Рязановского, В.О. Ключевского, С.Ф. Платонова и В.В. Похлебкина.

Мы не ставим перед собой цели ответить на вопрос о взаимодействии Орды и Руси однозначно, так как дать исчерпывающее основание для той или иной точки зрения не представляется возможным. Однако мы постараемся систематизировать имеющуюся информацию и выработать свою субъективную позицию по исследуемой теме.

Для того, чтобы попытаться определить степень и характер влияния Золотой Орды на Русь и наоборот, мы выработали четыре аспекта диалога культур, по которым мы будем проводить наше исследование: право, государство, сельское хозяйство и кустарное производство, культура и религия.

Право. Сравнивая две правовые системы, следует сразу отметить, что Русь тяготела прежде всего к заимствованию Византийского, а оттуда -римского права, в то время как Золотая Орда создавала свое право на основе прежде всего азиатских систем: китайской, персидской и иных. Одним из важнейших памятников монгольского права является Яса Чингисхана - специальный свод законов, принятый на курултае во времена правления хана Чингиза. Интересным фактом является то, что Яса не действовала на территории Руси все время ее вассального положения по отношению к Орде. В.А. Рязановский по этому поводу отмечает, что монголы не создали никакого специального кодекса для Руси, в то время как в этот же исторический период появляется знаменитый памятник русского права - Псковская судная грамота, который, по мнению Рязановского, намного превосходит все памятники монгольского права по юридической технике и содержанию. Касаемо гражданско-правовых отношений, автор также не выявляет взаимодействия двух правовых систем, поскольку совершенно разные типы хозяйствования и гражданского оборота не позволяли провести какие-либо заимствования [6, с. 158]. Мы склонны согласиться в этом вопросе с В.А. Рязановским, так как анализ правовых памятников показывает, что правовые системы Золотой Орды и Руси имели диаметрально противоположные черты. Если какое-либо влияние и имело место, то только заимствование отдельных видов правовых документов (к примеру, тарханные грамоты продолжали свое существование на Руси еще долгое время после татаро-монгольского ига).

Государство. Краеугольным камнем в вопросе влияния Золотой Орды на историческую судьбу Руси является вопрос о государственности и суверенитете. Повлияло ли негативно нашествие монголов на формирование Российского 
государства? В. А. Рязановский, В. О. Ключевский и Э. С. Кульпин солидарны в том, что монголы практически не занимались вопросами управления на Руси, а выдача ярлыков и определение баскаков были лишь формальностью. Однако В.А. Рязановский, в отличие от своих коллег, считает, что до татаромонгольского ига на Руси имел место расцвет государственности, а нашествие татаро-монголов надолго приостановило развитие данного процесса [6, с. 162]. В. О. Ключевский же считает, что порядка на Руси до пришествия монголов не было, и власть хана была благом для русичей, «батогом божиим», предотвращала произвол князей и дележку земель [2, с. 366]. Э.С. Кульпин также солидарен с этой точкой зрения, характеризуя отношения между князьями как «одичание и братское озлобление» [3, с. 22] . Мы склонны согласиться с В.О. Ключевским и Э.С. Кульпиным: развитой государственности на Руси не было и до татаро-монгольского ига, а торможение в ее развитии не связано напрямую с Ордой, а скорее проистекает из внутренних особенностей управления на Руси. Таким образом, мы отвергаем точку зрения о том, что Золотая Орда каким-либо образом повлияла на отставание развития российской государственности. Однако мы склонны согласиться с В.В. Похлебкиным в том, что Золотая Орда косвенно помогла переориентировать русскую государственную машину на Азию [4, с. 17].

Сельское хозяйство и кустарное производство. Не секрет, что Золотая Орда угоняла пленных ремесленников и крестьян на работы в административный центр. Как же это сказалось на развитии русского сельского хозяйства и кустарного производства? Существуют данные, что с момента набега монголов на Русь, на долгое время прекратилось каменное строительство в русских городах. Также многим известны особенности передачи ремесла на Руси - умения и навыки передавались от отца к сыну. Таким образом, если отцаремесленника угнать на работы в Орду, то его сын никогда не сможет получить должных профессиональных навыков, ведь специальных школ для освоения ремесел не существовало.

Что касается сельского хозяйства, то следует отметить, что монгольские степи и русские земли сильно отличались по составу почвы, что определяло различные системы земледелия для Золотой Орды и Руси. Русское сельское хозяйство ориентировано на распашку плодородных, полных влаги земель. Монгольское сельское хозяйство не приемлет частой распашки, так как это губительно сказывается на количестве и качестве урожая. Таким образом, данные системы не могли пересекаться. Даже если русский крестьянин был бы 
обучен методам монгольского земледелия, он не смог бы применить эти навыки на родной почве.

Более того, нет сведений о том, чтобы монголы стабильно посылали отряды на Русь для изъятия продуктов питания. Так же как и нет сведений о том, чтобы русские употребляли продукты питания из Орды. Таким образом, системы земледелия и потребления обоих государств могли существовать параллельно, не затрагивая друг друга.

Мы приходим к выводу, что Золотая Орда повлияла на развитие только лишь ремесленной составляющей производства на Руси, так как неоднократно прерывала преемственность ремесленных знаний путем угона мастеров на работы в Орду. Сельское хозяйство Руси существовало и развивалось планомерно, не находясь под влиянием монгольских методов.

Культура и религия. С.Ф. Платонов признает, что на русском востоке 1315 вв. существовала некоторая культурная отсталость и некий налет «татарщины». Однако он отмечает, что не следует преувеличивать силу этого татарского культурного влияния, так как добровольно русские ничего не перенимали у тех, кого считали «погаными». Наиболее отчетливый диалог двух культур прослеживается уже при ослаблении татаро-монгольского ига, когда монголы перестают носить титул «завоевателей и хозяев». Однако и этот диалог не стоит оценивать слишком высоко. Дальше заимствований лексики и некоторых черт быта и одежды дело не пошло [5, с. 84-85]. Мы считаем, что нельзя однозначно утверждать, что заимствование некоторых аспектов чужой культуры является отрицательным явлением - это удел консерваторов. Наше мнение состоит в том, что заимствование отдельных вещей из культуры татаромонголов не привело к деградации русской культуры, но к ее обогащению.

Что касается религии, то Э.С. Кульпин утверждает, что Орда была максимально веротерпима [3, с. 40-41]. Монголы не навязывали своих верований не только покоренным народам, но и своим соотечественникам - сыновья ханов, к примеру, могли выбирать любой понравившийся им религиозный культ. Известно, что русская церковь была освобождена от налогов и пользовалась уважением хана. Таким образом, однозначен вывод о том, что Золотая Орда никак не затронула религиозную сферу русского государства. Более того, мы считаем, что тогдашней и поздней Руси следовало бы поучиться у монголов веротерпимости и лояльности к религии.

В итоге, по всем четырем критериям нами не было выявлено прямого негативного влияния Золотой Орды на развитие Руси как суверенного 
государства. Мы выявили некоторые положительные аспекты диалога культур, однако, не следует переоценивать их ценность.

Таким образом, мы не можем сказать, что татаро-монгольское иго явилось серьезным катализатором развития или торможения русской государственности как таковой. Мы склоняемся к мысли, что на историческую судьбу России прежде всего повлияли ее внутренние факторы, нежели внешние.

Вопрос о взаимодействии Золотой Орды и Руси все еще остается открытым ввиду невозможности дать однозначный ответ по данной теме. Полагаем, что переоценка событий будет происходить и далее, но вероятность прийти к единому мнению при условии субъективности высказываний каждого отдельного историка и огромного влияния на его образ мышления современной ему эпохи очень мала.

1. Касимов P.X. Возрождение мироимперий: категория цивилизации в контексте миросистемного анализа // Исторические, философские, политические и юридические науки, культурология и искусствоведение. Вопросы теории и практики. №8(58): в 3 ч. Ч. II. 2015. - С. 96-98.

2. Ключевский В. О. Русская история. Полный курс лекций. В 3 кн. Кн. 1. М., 1993.

3. Кульпин Э. С. Золотая Орда. Проблемы генезиса Российского государства. М., 1998.

4. Похлебкин В. В. Татары и Русь: 360 лет отношений Руси с татарскими государствами в XIII-XVI вв. 1238-1598 : справочник. М., 2000.

5. Платонов С. Ф. Учебник русской истории. М., 1992.

6. Рязановский В. А. К вопросу о влиянии монгольской культуры и монгольского права на русскую культуру и право // Вопр. истории. 1993. № 7. 